ZOOLOGIA 31 (2): 147-152, April, 2014

http://dx.doi.org/10.1590/S1984-46702014000200005

\title{
Environmental parameters affecting the structure of leaf-litter frog (Amphibia: Anura) communities in tropical forests: A case study from an Atlantic Rainforest area in southeastern Brazil
}

\author{
Carla C. Siqueira',2, Davor Vrcibradic ${ }^{3}$, Paulo Nogueira-Costa ${ }^{4}$, Angele R. Martins ${ }^{4}$, Leonardo \\ Dantas $^{2}$, Vagner L. R. Gomes ${ }^{2}$, Helena G. Bergallo² \& Carlos Frederico D. Rocha ${ }^{2}$
}

\author{
${ }_{1}$ Programa de Pós-Graduação em Ecologia, Instituto de Biologia, Universidade Federal do Rio de Janeiro. Avenida Carlos \\ Chagas Filho 373, Bloco A, Cidade Universitária, 21941-902 Rio de Janeiro, RJ, Brazil. E-mail: carlacsiqueira@yahoo.com.br \\ ${ }^{2}$ Departamento de Ecologia, Universidade do Estado do Rio de Janeiro. Rua São Francisco Xavier 524, Maracanã, \\ 20550-013 Rio de Janeiro, RJ, Brazil. \\ ${ }_{3}^{3}$ Departamento de Zoologia, Universidade Federal do Estado do Rio de Janeiro. Avenida Pasteur 458, Urca, 22290-240 Rio \\ de Janeiro, RJ, Brazil. \\ ${ }^{4}$ Departamento de Vertebrados, Museu Nacional, Universidade Federal do Rio de Janeiro. Quinta da Boa Vista, \\ 20940-040 Rio de Janeiro, RJ, Brazil.
}

\begin{abstract}
Despite a recent increase of information on leaf litter frog communities from Atlantic rainforests, few studies have analyzed the relationship between environmental parameters and community structure of these animals. We analyzed the effects of some environmental factors on a leaf litter frog community at an Atlantic Rainforest area in southeastern Brazil. Data collection lasted ten consecutive days in January 2010, at elevations ranging between 300 and $520 \mathrm{~m}$ above sea level. We established 50 quadrats of $5 \times 5 \mathrm{~m}$ on the forest floor, totaling $1,250 \mathrm{~m}^{2}$ of sampled area, and recorded the mean leaf-litter depth and the number of trees within the plot, as well as altitude. We found 307 individuals belonging to ten frog species within the plots. The overall density of leaf-litter frogs estimated from the plots was 24.6 ind $/ 100 \mathrm{~m}^{2}$, with Euparkerella brasiliensis (Parker, 1926), Ischnocnema guentheri (Steindachner, 1864), Ischnocnema parva (Girard, 1853) and Haddadus binotatus (Spix, 1824) presenting the highest estimated densities. Among the environmental variables analyzed, only altitude influenced the parameters of anuran community. Our results indicate that the study area has a very high density of forest floor leaf litter frogs at altitudes of 300-500 m. Future estimates of litter frog density might benefit from taking the local altitudinal variation into consideration. Neglecting such variation might result in underestimated/overestimated values if they are extrapolated to the whole area.
\end{abstract}

KEY WORDS. Frog richness; density estimates; environmental factors.

Community ecology aims to understand the patterns of distribution, abundance and interactions among organisms (Leibold et al. 2004, Keller et al. 2009). However, it is not always clear which factors are responsible for community structure, and whether species assemblies follow any general rules. While ecotones and physical factors are important in structuring amphibian communities, competitive interactions seem to exert comparatively little influence (HOFER et al. 1999, 2000, 2004, Keller et al. 2009).

The Brazilian Atlantic rainforest possibly harbors the world's greatest diversity of frog species, most of which are endemic (Duellman 1999, Haddad \& Prado 2005). Since the mid1990s, more information on leaf litter frog communities from Atlantic rainforest areas has become available (e.g., GIARETTA et al. 1997, 1999, RосHA et al. 2000, 2001, 2007, 2011, 2013, VAN Stuys et al. 2007, Almeida-Gomes et al. 2008, Siqueira et al. 2009,
SANTOS-Pereira et al. 2011). Nevertheless, few studies have analyzed the relationship between environmental parameters and community structure of leaf litter frogs (GiaretTa et al. 1997, 1999, Van Sluys et al. 2007, Santos-Pereira et al. 2011). Furthermore, the available information is still insufficient to identify patterns. Consequently, the main factors explaining the local density and richness of frogs in Atlantic Rainforest areas are still poorly understood.

A short-term inventory of the leaf litter frogs of an Atlantic Rain Forest Reserve, Reserva Ecológica de Guapiaçu (REGUA, state of Rio de Janeiro, southeastern Brazil), has provided data on community composition, abundance and density of those frogs (Rocha et al. 2007). In the present study, we analyzed the extent to which certain environmental factors affect the richness and abundance of leaf litter frogs in the same reserve. We also provide new estimates of leaf litter frog 
density and richness for the area. Our aim was to investigate the factors explaining the local ecological parameters of tropical frog communities.

\section{MATERIAL AND METHODS}

The study was carried out at the Reserva Ecológica de Guapiaçu (hereafter REGUA, $22^{\circ} 24^{\prime} \mathrm{S}, 42^{\circ} 44^{\prime} \mathrm{W}$ ), municipality of Cachoeiras de Macacu, Rio de Janeiro State, southeastern Brazil. The area is inserted within one of the largest remnants of Atlantic forest in the state (over 60,000 ha), most of which is encompassed by the Três Picos State Park. Most of the area is covered with Atlantic Rainforest in different levels of conservation, with remnants of undisturbed forests occurring in the higher and less accessible areas of the reserve. The climate is wet and warm, with mean annual rainfall of about $2,600 \mathrm{~mm}$ and daily temperatures ranging from 14 to $37^{\circ} \mathrm{C}$ (BERNARDO et al. 2011).

We sampled during ten consecutive days (from 20 to 29 January 2010), at elevations ranging between 300 and $520 \mathrm{~m}$ above sea level. We established 50 plots (quadrats) of $5 \times 5 \mathrm{~m}$ $\left(25 \mathrm{~m}^{2}\right)$ (see JAEGER \& INGER 1994) on the forest floor (five per day), totaling $1250 \mathrm{~m}^{2}$ of sampled area. Each quadrat was an independent sampling unit and was at least $100 \mathrm{~m}$ apart from the nearest one. While setting the plots, we also maintained a minimum distance of $10 \mathrm{~m}$ from streams, in order to minimize the effect of the proximity of water bodies on the frogs (except in one case, where the plot was set ca. $6 \mathrm{~m}$ from a stream). During the day, we delimited quadrats by completely enclosing them with a $80 \mathrm{~cm}$ high soft mesh fence. The bottom of the fence was buried or attached to the ground with strings and sticks, to prevent frogs from escaping the plot (RосHA et al. 2001). After sunset, each plot was carefully searched for frogs by a crew of four people wearing head lamps. During searches, each crew member walked the entire plot on hands and knees, side-by-side, using hand rakes. Inside each plot, crew members checked for frogs on and underneath leaves and pieces of dead wood, rock crevices and spaces between tree roots. Additionally, they overturned fallen branches and stones. Searches in each plot lasted about 20-30 minutes. All anurans encountered within a given plot were identified to species and released after the crew had finished searching. Although no individuals were collected in the present study (except for a caecilian), voucher specimens of all frog species recorded herein, collected at the study area during previous fieldwork, are deposited at the Museu Nacional, Rio de Janeiro (see Appendix). For each plot, we recorded the altitude, estimated the mean leaf-litter depth (by measuring the litter depth at each corner of the plot and calculating the mean value), and counted the number of trees with a trunk diameter (DBH) wider than $50 \mathrm{~mm}$.

The evaluation of collection effectiveness was undertaken by a species accumulation curve (collector curve) and by estimators (Bootstrap and Chao 1), using the program EstimateS 8.2.0 (Colwell 2005). To analyze the relative importance of some environmental parameters such as leaf litter depth, altitude and number of trees affecting the abundance and richness of leaf litter frogs, we performed multiple regression analyses with frog abundance/richness as the dependent variable and environmental parameters as the independent variables.

The influence of the environmental variables altitude, mean leaf-litter depth and number of trees on anuran species distribution (composition data) was assessed through a Canonical Correspondence Analysis (CCA; Ter BraAK 1986). Data on environmental factors were standardized by centering and normalizing. The statistical significance of the species-environment correlation was evaluated by Monte Carlo test (1000 randomized runs).

\section{RESULTS}

A total of 307 individuals belonging to ten frog species were found in the plots (Table I). The number of frogs per plot ranged from zero $(5 / 50$ or $10.0 \%$ of all plots) to 26 ( $1 / 50$ or $0.02 \%$ ) with a median value of 4.5 frogs per plot and a mean value of $6.1 \pm 6.3$ frogs per plot. The overall density of leaf-litter frogs estimated from the plots was $24.6 \mathrm{ind} / 100 \mathrm{~m}^{2}$. Euparkerella brasiliensis (Parker, 1926) (7.0 ind/100 m²), Ischnocnema guentheri (Steindachner, 1864) $(5.7$ ind/100 m²), Ischnocnema parva (Girard,

Table I. Total number of individuals sampled and estimated density (individuals $/ 100 \mathrm{~m}^{2}$, in parenthesis) of each frog species found in the leaf-litter frog community of the Atlantic rainforest of Reserva Ecológica de Guapiaçu, southeastern Brazil, using 5 × 5 plot sampling method. ( $\left.{ }^{*}\right)$ Nine individuals of unidentified species evaded capture.

\begin{tabular}{lc}
\hline \multicolumn{1}{c}{ Frog species } & $\begin{array}{c}\text { Number of individuals } \\
\text { (density) }\end{array}$ \\
\hline Brachycephalidae & $15(1.2)$ \\
Brachycephalus didactylus (Izecksohn, 1971) & $71(5.7)$ \\
Ischnocnema guentheri (Steindachner, 1864) & $55(4.4)$ \\
Ischnocnema parva (Girard, 1853) & \\
Craugastoridae & $43(3.4)$ \\
$\quad$ Haddadus binotatus (Spix, 1824) & $88(7.0)$ \\
Euparkerella brasiliensis (Parker, 1926) & $11(0.9)$ \\
Cycloramphidae & \\
$\quad$ Zachaenus parvulus (Girard, 1853) & $1(0.1)$ \\
Hylodidae & \\
$\quad$ Crossodactylus aeneus Müller, 1924 & $7(0.6)$ \\
Leptodactylidae & $6(0.5)$ \\
Adenomera marmorata Steindachner, 1867 & \\
Physalaemus signifer (Girard, 1853) & $1(0.1)$ \\
Microhylidae & $307(24.6)$ \\
$\quad$ Chiasmocleis carvalhoi Cruz, Caramaschi \& & \\
Izecksohn, 1997 & \\
\hline Total (*) & \\
\hline
\end{tabular}


1853) (4.4 ind/100 $\left.\mathrm{m}^{2}\right)$ and Haddadus binotatus (Spix, 1824) (3.4 ind $/ 100 \mathrm{~m}^{2}$ ) presented the highest estimated densities (Table I). Those four species accounted for $83.7 \%$ of all frogs found in the plots. In addition to frogs, one individual of the caecilian Siphonops hardyi Boulenger, 1888 (Gymnophiona, Siphonopidae) was found inside a plot. The species accumulation curve analysis produced a clear asymptotic shape, and the predicted estimates of frog richness (Bootstrap $=10.8 \pm 0.3$ species; Chao $1=$ $11.0 \pm 2.3$ species) were close to the richness value obtained by us with plot sampling (10 species) (Fig. 1).

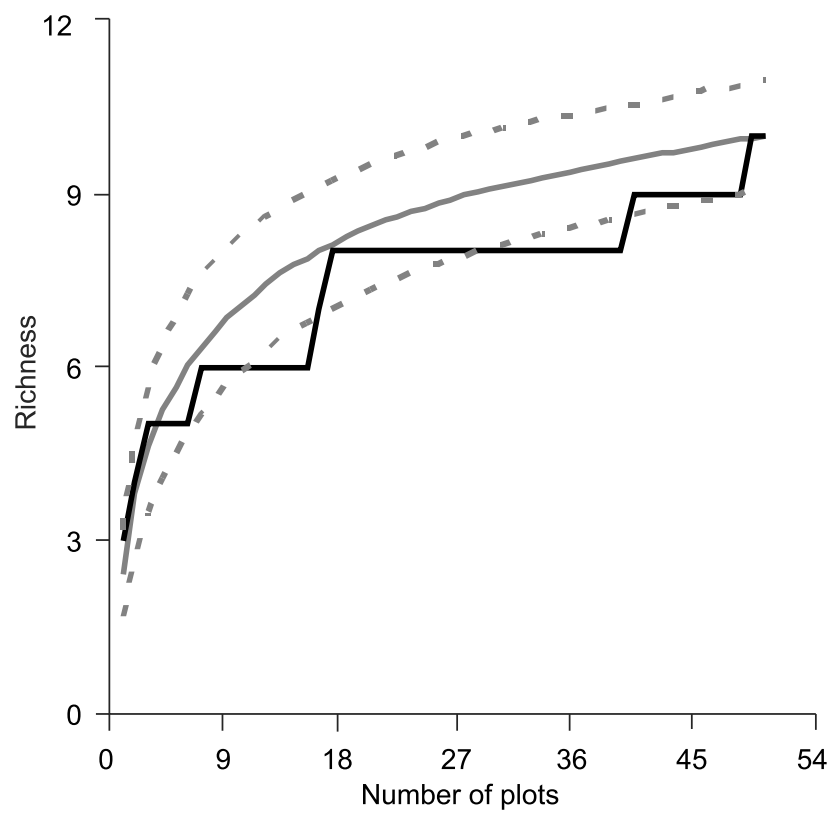

Figure 1. Cumulative (black line) and rarefaction (solid gray line; with the standard deviation represented by dotted gray lines) curves of richness of leaf litter frogs recorded at the Atlantic rainforest of Reserva Ecológica de Guapiaçu, in southeastern Brazil, using $5 \times 5$ plot sampling method.

The overall abundance of frogs and the three environmental variables (altitude, leaf litter depth and number of trees) were not significantly correlated in the results of the multiple regression analysis $\left(\mathrm{r}=0.39, \mathrm{~F}_{3,46}=2.68, \mathrm{p}=0.06\right)$. Partial correlations showed a positive and significant relationship between frog abundance and altitude $(\mathrm{p}<0.01)$, but not for the other variables (leaf litter depth, $p=0.60$; number of trees, $p=0.63$ ).

Frog richness was not significantly influenced by the combined effect of the three environmental variables tested, according to the multiple regression analysis $\left(\mathrm{r}=0.36, \mathrm{~F}_{3,46}=2.22, \mathrm{p}=\right.$ $0.10)$. Partial correlations showed a positive and significant relationship between frog richness and altitude $(p<0.05)$, but not for the remaining variables (leaf litter depth, $p=0$. 80; number of trees, $\mathrm{p}=0.46$ ).
The first three axes of the CCA explained only $9.9 \%$ of the variance in species data $(6.0,2.7$, and $1.2 \%$, respectively). The biplot scores of the variable "altitude" showed a higher correlation to axis $1(=-0.345)$, while "number of trees" had a higher correlation with axis $2(=0.216)$ (Table II). Randomization (Monte Carlo) test did not show statistical significance for species-environment correlations ( $\mathrm{p}=0.07$ for axis 1 ; $\mathrm{P}$ was not reported for axes 2 and 3 because using a simple randomization test for these axes could bias the $\mathrm{P}$ values).

Table II. Summary of the CCA performed for three features used to characterize plots and anuran species distribution among them at the Reserva Ecológica de Guapiaçu, southeastern Brazil. The variable scores with the highest influence in the first two axes are shown in boldface.

\begin{tabular}{lccc}
\hline & Axis 1 & Axis 2 & Axis 3 \\
\hline $\begin{array}{llll}\text { Correlations (biplot scores) } \\
\quad \text { Leaf litter depth }\end{array}$ & -0.109 & 0.126 & -0.132 \\
$\quad$ Altitude & -0.345 & -0.055 & 0.047 \\
$\quad$ Number of trees & -0.024 & 0.216 & 0.078 \\
$\begin{array}{l}\text { Summary statistics for ordination axes } \\
\quad \text { Eigenvalues }\end{array}$ & & & \\
$\quad \begin{array}{l}\text { Species-environment } \\
\quad \text { Correlations }\end{array}$ & 0.137 & 0.061 & 0.027 \\
\hline
\end{tabular}

\section{DISCUSSION}

With this study, four species, namely Brachycephalus didactylus (Izecksohn, 1971), Crossodactylus aeneus Müller, 1924, I. parva, and Zachaenus parvulus (Girard, 1853), are added to the list of leaf litter frogs of the REGUA, previously compiled by Rocha et al. (2007), and which featured 12 species. However, these previous records include the hylid Scinax aff. $x$ signatus, a scansorial species that is considered accidental in the leaf litter, and Euparkerella brasiliensis, which was erroneously identified as E. cochranae Izeksohn, 1988 in that work (L.A. Fusinatto, pers. comm.). Thus, there are currently 15 species known to comprise the leaf litter frog community of the REGUA (excluding Scinax aff. $x$-signatus which we do not consider as a leaf litter inhabitant). Most of those species are typical constituents of anuran communities in the leaf litter floor of Atlantic Forest areas in southeastern Brazil (e.g., Rocha et al. 2000, 2007, 2011, Almeida-Gomes et al. 2008, Siqueira et al. 2009, ARAújo et al. 2009). However, the hylodid C. aeneus is typically found in association with streams (JORDão-NogUEIRA et al. 2006), and the only individual recorded during our study was found in a plot set ca. $6 \mathrm{~m}$ from a small stream.

Despite the fact that our focus was on leaf litter anurans, it is worth mentioning that we also recorded the caecilian $S$. hardyi during our fieldwork. This finding represents another new record of a forest floor amphibian for the REGUA. 
In the present study, the estimated density of forest floor leaf litter frogs at the REGUA $\left(24.6 \mathrm{ind} / 100 \mathrm{~m}^{2}\right)$ was about three times higher than that of a previous plot study carried out in the same locality ( $8.4 \mathrm{ind} / 100 \mathrm{~m}^{2}$, Rocha et al. 2007). It is possible that the different densities found in the two studies are, at least in part, related to the altitude: from $300-520 \mathrm{~m}$ a.s.l. in our study versus $100-400 \mathrm{~m}$ a.s.l. (but predominantly at the lower sites) in the study of Rocha et al. (2007). Another plot study carried out between 500 and $800 \mathrm{~m}$ a.s.l., in a site only ca. $15 \mathrm{~km}$ distant from the REGUA, also yielded relatively high litter frog density estimates $\left(17.1 \mathrm{ind} / 100 \mathrm{~m}^{2}\right.$ ) (Siqueira et al. 2009). It is also possible that the months of sampling may have been responsible for part of the differences between our study (January - peak of the rainy season) and that of Roche et al. (2007) (October - beginning of the rainy season), since Atlantic Forest leaf litter frog composition and abundances may vary seasonally (e.g., Santos-Pereira et al. 2011).

The litter frog density estimated for the REGUA in our study was not only higher than previously reported for the same region, but also higher than in all other Atlantic Forest areas for which similar data are available (see RocHA et al. 2013). Comparing our data with other studies in different tropical forest regions in South America, the estimated density for the REGUA was higher than in some Amazon rainforest areas in Brazil (3.06.0 ind $/ 100 \mathrm{~m}^{2}$; Allmon 1991) and in Peru (4.4-15.5 ind $/ 100 \mathrm{~m}^{2}$; ToFт 1980a). Compared to rainforest sites in Central America, our density estimate was higher (11.5 ind $/ 100 \mathrm{~m}^{2}$ - HeInen 1992 ; 15.7 ind/100 $\mathrm{m}^{2}$ - LIEBERMAN $1986 ; 7.5-19.4 \mathrm{ind} / 100 \mathrm{~m}^{2}$ - ToFT 1980b), lower (30.2 ind/100 $\mathrm{m}^{2}-$ HeATWOLE \& SEXTON 1966), or higher/lower (13.4-62.3 ind/100 $\mathrm{m}^{2}$ - SCOTT JR 1976), depending on the locality and/or time of the year when sampling was performed. On the other hand, the estimated leaf-litter frog density obtained in our study was higher than reported for most Old World tropical forests surveyed so far (e.g., 0.5-2.6 ind/100 $\mathrm{m}^{2}$ in Thailand - Inger \& Colwell 1977; 1.2 ind/100 $\mathrm{m}^{2}$ in Borneo - Lloyd et al. 1968; 1.5-2.2 ind/100 $\mathrm{m}^{2}$ in Uganda - Vonesh 2001; $1.5 \mathrm{ind} / 100 \mathrm{~m}^{2}$ in the southern Western Ghats, India - VASUdEvan et al. 2008; 9.4 ind/100 $\mathrm{m}^{2}$ in Cameroon - Sсотт JR 1982; 3.5$10.2 \mathrm{ind} / 100 \mathrm{~m}^{2}$ in Taiwan - HuANG \& Hou 2004), with one exception (41.8 ind $/ 100 \mathrm{~m}^{2}$ in Iriomote island, Japan - WatanABE et al. 2005). Hence, our data generally support the idea that higher densities of leaf-litter frogs tend to occur in the Neotropical region compared to the Old World tropics.

We detected a significant effect of altitude on the richness and abundance of the leaf litter anuran community at REGUA, despite the relatively small altitudinal range included in our study (ca. $200 \mathrm{~m}$ ). The influence of altitude on anuran community parameters could be due to variation in environmental factors such as temperature and humidity, for instance (e.g., Giaretta et al. 1999). Moreover, it is possible that habitat quality varies with altitude within the area, with more disturbances at lower sites resulting in comparatively less favorable conditions for leaf litter frogs (e.g., Rocha et al. 2013). A longer- term study monitoring environmental parameters and quantifying habitat quality (or disturbance), including a wider altitudinal gradient, may clarify the relationship between altitude and leaf litter frog density.

Altitude, in our analysis, was the only variable that significantly affected the parameters of the leaf litter frog community. GiaretTa et al. (1999) found that altitude, depth of soil cover, leaf litter mass and fallen trunk area all influence the density of leaf litter frogs at an Atlantic Forest area in the state of São Paulo, Brazil. VAN SLuys et al. (2007), in a study conducted at the island of Ilha Grande (Rio de Janeiro State), found that mean litter depth and the proportion of leaves in the leaf litter were significantly correlated with abundance and richness of litter frogs (VAN SLuYs et al. 2007). In a "restinga" habitat (a relatively xeric ecosystem within the Atlantic Forest biome) in northeastern Brazil, the amount of leaves, percentage of leaf litter, percentage of terrestrial bromeliads exposed to direct sunlight, number of terrestrial bromeliads and soil moisture were the environmental variables that better explained the composition of the local anuran community (BASTAZINI et al. 2007). At a site in the Brazilian Amazon, Allmon (1991) did not obtain any significant results regarding the influence of leaf litter moisture, depth or average dry mass on the abundance of frogs, but plots with frogs had higher average dry litter mass than plots without frogs. FAUTH et al. (1989) found a negative effect of elevation and a positive effect of leaf litter depth on the density and richness of amphibians in Costa Rica. Data from the aforementioned studies indicate that the effect of different environmental variables on the richness and densities of tropical forest floor herpetofauna varies among sites, but the amount/depth of leaf litter seems to be a consistently important variable overall. In the present study, however, litter depth was not significantly correlated with frog abundance or richness, contrary to what would be expected based on previous studies in other areas.

The results of the present study indicate that the area of the REGUA has a very high density of forest floor leaf litter frogs at altitudes of 300-500 m. This, together with the significant effect of altitude on litter frog abundance and richness in our analyses (and comparisons with an earlier study done mostly at lower altitudes in the same area), shows that estimates of litter frog density within a given area should consider the local altitudinal variation, and that data obtained at a limited altitudinal range may lead to underestimated/overestimated values if extrapolated to the whole area.

\section{ACKNOWLEDGEMENTS}

We thank Nicholas J. Locke of the Reserva Ecológica de Guapiaçu (REGUA) for facilitating this study, giving logistical support and for the permit to work in the area; the Instituto Estadual do Ambiente (INEA) for the license (\# 005/2008). Carlos F.D. Rocha received resources from the Conselho Nacional de Desenvolvimento Científico e Tecnológico - CNPq (Processes 
307653/2003-0 and 476684/2008-0) and from the Fundação de Amparo à Pesquisa do Estado do Rio de Janeiro - FAPERJ (Process E-26/102.404/2009) through the program "Cientistas do Nosso Estado". This project also beneffited from funding of the "Edital Espécies Ameaçadas" of Fundação Biodiversitas/CEPAN and RAN/ICMBio (Project 0158A/012006). During this study Carla C. Siqueira received a PhD grant from the CNPq (Process $141555 / 2008-4)$, and currently receives postdoctoral grants also from CNPq (Process 150151/2012-8). Helena G. Bergallo thanks FAPERJ and CNPq for the research grants.

\section{LITERATURE CITED}

AlLmon, W.D. 1991. A plot study of forest floor litter frogs, central Amazon, Brazil. Journal of Tropical Ecology 7 (4): 503522. doi: 10.1017/S0266467400005885

Almeida-Gomes, M.; D. Vrcibradic; C.C. Siqueira; M.C. Kiefer; T. Klaion; P. Almeida-Santos; D. Nascimento; C.V. Ariani; V.N.T. Borges-Junior; R.F. Freitas-Filho; M. VAN Sluys \& C.F.D. Rocha. 2008. Herpetofauna of an Atlantic Rainforest area (Morro São João) in Rio de Janeiro State, Brazil. Anais da Academia Brasileira de Ciências 80 (2): 291-300. doi: 10.1590/S000137652008000200007

Araújo, O.G.S.; L.F. Toledo; P.C.A. Garcia \& C.F.B. Haddad. 2009. The amphibians of São Paulo State, Brazil. Biota Neotropica 9 (4): 197-209. doi: 10.1590/S1676-06032009000400020

Bastazin, C.V.; J.F.V. Munduruca; P.L.B. Rocha \& M.F. Napoli. 2007. Which environmental variables better explain changes in anuran community composition? A case study in the restinga of Mata de São João, Bahia, Brazil. Herpetologica 63 (4): 459 471. doi: 10.1655/0018-0831(2007)63[459:wevbec]2.0.co;2

Bernardo, C.S.S.; H. Lloyd; N. Bayly \& M. Galetti. 2011. Modelling post-release survival of reintroduced Red-billed Curassows Crax blumenbachii. Ibis 153 (3): 562-572. doi: 10.1111/j.1474-919x.2011.01142.x

Colwell, R.K. 2005. Estimates: Statistical estimation of species richness and shared species from samples. Version 7.5. Available online at: ?? [Accessed: ??/??/20??].

Duellman, W.E. 1999. Distribution Patterns of Amphibians in South America, p. 255-327. In: W.E. Duellman (Ed.). Patterns of Distribution of Amphibians. Baltimore and London, The Johns Hopkins University Press, VII + 648p.

Fauth, J.E.; B.I. Crother \& J.B. SLowinski. 1989. Elevational patterns of species richness, evenness and abundance of the Costa Rican leaf-litter herpetofauna. Biotropica 21 (2): 178185.

Giaretta, A.A.; R.J. Sawaya; G. Machado; M.S. Araújo; K.G. Facure; H.F. Medeiros \& R. Nunes. 1997. Diversity and abundance of litter frogs at altitudinal sites at Serra do Japi, Southeastern Brazil. Revista Brasileira de Zoologia 14 (2): 341-346. doi: 10.1590/S0101-81751997000200008

Giaretta, A.A.; K.G. Facure; R.J. Sawaya; J.H.D. Meyer \& N. Chemin. 1999. Diversity and abundance of litter frogs in a montane forest of southeastern Brazil: seasonal and altitudinal changes. Biotropica 31 (4): 669-674. doi: 10.1111/j.17447429.1999.tb00416.x

Haddad, C.F.B. \& C.P.A. Prado. 2005. Reproductive modes in frogs and their unexpected diversity in the Atlantic Forest of Brazil. BioScience 55 (3): 207-217. doi: 10.1641/00063568(2005)055[0207:RMIFAT]2.0.CO;2

Heatwole, H. \& O.J. Sexton. 1966. Herpetofaunal comparisons between two climatic zones in Panama. American Midland Naturalist 75 (1): 45-60. doi: 10.2307/2423482

HeInen, J.T. 1992. Comparisons in the leaf litter herpetofaunas in abandoned cacao plantations and primary rain forest in Costa Rica: some implications for faunal restoration. Biotropica 24 (3): 431-439.

Hofer, U.; L.F. Bersier \& D. BorCARd. 1999. Spatial organization of a herpetofauna on an elevational gradient revealed by null model tests. Ecology 80 (3): 976-988. doi: 10.1890/ 0012-9658(1999)080[0976:SOOAHO]2.0.CO;2

Hofer, U.; L.F. Bersier \& D. BorCARD. 2000. Ecotones and gradient as determinants of herpetofaunal community structure in the primary forest of Mount Kupe, Cameroon. Journal of Tropical Ecology 16 (4): 517-533.

Hofer, U.; L.F. Bersier \& D. Borcard. 2004. Relating niche and spatial overlap at the community level. Oikos 106 (2): 366376. doi: 10.1111/j.0030-1299.2004.12786.x

HuAnG, C.H. \& P.C.L. Hou. 2004. Density and diversity of litter Amphibians in a monsoon forest of southern Taiwan. Zoological Studies 43 (4): 795-802.

INGER, R.F. \& R.K. CoLwELL. 1977. Organization of contiguous communities of amphibians and reptiles in Thailand. Ecological Monographs 47 (3): 229-253. doi: 10.2307/1942516

JAEGER. R. \& R.F. INGER. 1994. Standard techniques for inventory and monitoring: quadrat sampling, p. 97-102. In: W.R. HeYer, M.A. Donnelly, R.W. McDiarmid, L.A.C. HayeK \& M.S. Foster (Eds). Measuring and monitoring biological diversity: standard methods for amphibians. Washington, D.C., Smithsonian Institution Press, 364p.

Jordão-Nogueira, T.; D. Vrcibradic; J.A.L. Pontes; M. Van Sluys \& C.F.D. Rocha. 2006. Natural history traits of Crossodactylus aeneus (Anura, Leptodactylidae, Hylodinae) from an Atlantic forest area in Rio de Janeiro State, southeastern Brazil. South American Journal of Herpetology 1 (1): 37-41. doi: 10.2994/1808-9798(2006)1[37:NHTOCA]2.0.CO;2

Keller, A.; M.O. Rödel; K.E. Linsenmair \& T.U. Grafe. 2009. The importance of environmental heterogeneity for species diversity and assemblage structure in Bornean stream frogs. Journal of Animal Ecology 78 (2): 305-314. doi: 10.1111/ j.1365-2656.2008.01457.x

Leibold, M.A.; M. Holyoak; N. Mouquet; P. Amarasekare; J.M. Chase; M.F. Hoopes; R.D. Holt; J.B. Shurin; R. Law; D. Tilman; M. Loreau \& A. Gonzalez. 2004. The metacommunity concept: a framework for multi-scale community ecology. Ecology Letters 7 (7): 601-613. doi: 10.1111/j.1461-0248.2004.00608.x 
Lieberman, S.S. 1986. Ecology of the leaf litter herpetofaunas of a Neotropical rainforest: La Selva, Costa Rica. Acta Zoologica Mexicana 15 (1): 1-71.

LLOYD, M.; R.F. INGER \& W. KING. 1968. On the diversity of reptile and amphibian species in a Bornean rainforest. American Naturalist 102 (928): 497-515.

Rocha, C.F.D.; M. Van Sluys; M.A.S. Alves; H.G. Bergallo \& D. VRCibradic. 2000. Activity of leaf-litter frogs: when should frogs be sampled? Journal of Herpetology 34 (2): 285-287. doi: $10.2307 / 1565426$

Rocha, C.F.D.; M. Van Sluys; M.A.S. Alves; H.G. Bergallo \& D. Vrcibradic. 2001. Estimates of forest floor litter frog communities: a comparison of two methods. Austral Ecology 26 (1): 14-21. doi: 10.1111/j.1442-9993.2001.01073.pp.x

Rocha, C.F.D.; D. VRcibradic; M.C. Kiefer; M. Almeida-Gomes; V.N.T. Borges-Jr; P.C.F. Carneiro; R.V. Marra; P. Almeida-Santos; C.C. Siqueira; P. Goyannes-Araújo; C.G.A. Fernandes; E.C.N. Rubião $\&$ M. VAN SLuYs. 2007. A survey of the leaf-litter frog assembly from an Atlantic Forest area (Reserva Ecológica de Guapiaçu) in Rio de Janeiro State, Brasil, with an estimate of frog densities. Tropical Zoology 20 (1): 99-108.

Rocha, C.F.D.; D. Vrcibradic; M.C. Kiefer; C.C. Siqueira; M. Almeida-Gomes; V.N.T. Borges-Jr; F.H. Hatano; A.F. Fontes; J.A.L. Pontes; T. Klaion; L.O. Gil \& M. Van Sluys. 2011. Parameters from the community of leaf-litter frogs from Estação Ecológica Estadual Paraíso, Guapimirim, Rio de Janeiro State, southeastern Brazil. Anais da Academia Brasileira de Ciências 83 (4): 1259-1268.

Rocha, C.F.D.; D. Vrcibradic; M.C. Kiefer; M. Almeida-Gomes; V.N.T. Borges-Jr; V.A. Menezes; C.V. Ariani; J.A.L. Pontes; P. GoyannesAraújo; R.V. Marra; D.M. Guedes; C.C. Siqueira \& M. Van Sluys. 2013. The leaf-litter frog community from Reserva Rio das Pedras, Mangaratiba, Rio de Janeiro State, Southeastern Brazil: species richness, composition and densities. North-Western Journal of Zoology 9 (1): 151-156.

Santos-Pereira, M.; A. Candaten; D. Milani; F.B. Oliveira; J. Gardelin \& C.F.D. Rocha. 2011. Seasonal variation in the leaf-litter frog community (Amphibia: Anura) from an Atlantic Forest Area in the Salto Morato Natural Reserve, southern Brazil. Zoologia 28 (6): 755-761. doi: 10.1590/S1984-46702011000600008
ScotT JR, N.J. 1976. The abundance and diversity of the herpetofauna of tropical forest litter. Biotropica 8 (1): 41-58.

Sсотт JR, N.J. 1982. The herpetofauna of forest litter plots from Cameroon, Africa, p. 145-150. In: N.R.

SсотT JR (Ed.). Herpetological communities: a symposium of the Society for the Study of Amphibians and Reptiles and the Herpetologists' League. Washington, D.C., US Fish and Wildlife Service, 239p.

Siqueira, C.C.; D. Vrcibradic; M. Almeida-Gomes; V.N.T. BorgesJR; P. Almeida-Santos; M. Almeida-Santos; C.V. Ariani; D.M. Guedes; P. Goyannes-Araújo; T.A. Dorigo; M. Van Sluys \& C.F.D. Rосна. 2009. Density and richness of the leaf litter frogs of an Atlantic Rainforest area in Serra dos Órgãos, Rio de Janeiro State, Brazil. Zoologia 26 (1): 97-102. doi: 10.1590/ S1984-46702009000100015

Ter BraAK, C.J.F. 1986. Canonical correspondence analysis: a new eigenvector technique for multivariate direct gradient analysis. Ecology 67 (5): 1167-1179. doi: 10.2307/1938672

ToFт, C. 1980a. Feeding ecology of thirteen syntopic species of anurans in a seasonal tropical environment. Oecologia 45 (1): 131-141. doi: 10.1007/bf00346717

ToFT, C. 1980b. Seasonal variation in populations of Panamanian litter frogs and their prey: a comparison of wetter and drier sites. Oecologia 47 (1): 34-38. doi: 10.1007/bf00541772

Van Sluys, M.; D. Vrcibradic; M.A.S. Alves; H.G. Bergallo \& C.F.D. Rосна. 2007. Ecological parameters of the leaf-litter frog community of an Atlantic Rainforest area at Ilha Grande, Rio de Janeiro state, Brazil. Austral Ecology 32 (3): 254260. doi: 10.1111/j.1442-9993.2007.01682.x

Vasudevan, K.; A. Kumar; B.R. Noon \& R. Chellam. 2008. Density and diversity of forest floor anurans in the rain forests of southern Western Ghats, India. Herpetologica 64 (2): 207 215. doi: 10.1655/07-066.1

Vonesh, J.R. 2001. Patterns of richness and abundance in tropical Africa herpetofauna. Biotropica 33 (3): 502-510. doi: 10.1111/j.1744-7429.2001.tb00204.x

Watanabe, S.; N. NAKANISHI \& M. IZaWa. 2005. Seasonal abundance in the floor-dwelling frog fauna on Iriomote Island of the Ryuku Archipelago, Japan. Journal of Tropical Ecology 21 (1): 85-91. doi: 10.1017/S0266467404002068

Appendix. Voucher specimens of leaf-litter amphibians from the Reserva Ecológica de Guapiaçu deposited at the Museu Nacional, Rio de Janeiro (MNRJ).

Gymnophiona: Siphonops hardyi (MNRJ 65728); Anura: Adenomera marmorata (MNRJ 66561); Brachycephalus didactylus (MNRJ $55473-$ 74, 57736); Chiasmocleis carvalhoi (MNRJ 38105-07, 74592); Crossodactylus aeneus (MNRJ 82563); Euparkerella brasiliensis (MNRJ 37317-18; 38212-21); Haddadus binotatus (MNRJ 53620, 55476-78, 66160); Ischnocnema guentheri (MNRJ 53764, 55471-72, 59158); Ischnocnema parva (MNRJ 73201-02); Physalaemus signifer (MNRJ 59897, 66441); Zachaenus parvulus (MNRJ 55448, 56938-39).

Submitted: 23.I.2013; Accepted: 20.XII.2013. Editorial responsibility: Mauricio O. Moura 